\title{
THE EFFECT OF LAND TYPES AND CONSEQUENTLY LAND USE ON SOIL ORGANIC CARBON CONTENT - CASE STUDY: DAMAVAND REGION OF IRAN
}

\author{
DADGAR, M. \\ Department of Soil Sciences, Roudehen Branch, Islamic Azad University, Tehran, Iran \\ (e-mail: maryam.dadgar2008@gmail.com; phone:+98-912-630-2981) \\ (Received $29^{\text {th }}$ Apr 2018; accepted $5^{\text {th }}$ Jul 2018)
}

\begin{abstract}
Organic carbon is an important component of soil that influences soil fertility, biological activity, food security, and climate change. One of the important issues in soil science is the establishment of empirical relationships between different soil properties. The objectives of this research were to investigate the influence of different factors on soil organic carbon, such as total nitrogen, clay content, calcium carbonate equivalent and $\mathrm{pH}$, for soils from various geomorphologic settings in the Damavand Region in Northwest Tehran, Iran. Regression models were developed for prediction of the organic carbon content of soils characteristics in this region. Lower SOC concentrations were measured for plateau soils $\left(\sim 4.92 \mathrm{~g} \mathrm{~kg}^{-1}\right)$, associated with lower plant biomass and reduced temperatures at higher elevations. In contrast, soils from River Alluvial Plain regions, which are currently utilized for gardening, had the highest organic carbon content $\left(\sim 22.05 \mathrm{~g} \mathrm{~kg}^{-1}\right)$. For all landform types (i.e., alluvial fan (irrigated farming lands), plateau (Rangeland), and River Alluvial Plain soils (garden)), SOC had positive and significant relationship with total nitrogen $(r=0.962, \mathrm{p}<0.01)$. Simple linear regression, multiple linear regression, and nonlinear regression models were also developed for describing the relationship between SOC and landforms physical and chemical characteristics.
\end{abstract}

Keywords: physiographic characteristics, regression models, soil properties

\section{Introduction}

Current investigation attempted to enhance the amount of organic carbon captured in soils. Organic matter is one of the most important indicators of soil quality. Recent efforts have been made to increase the carbon storage capacity of soils, having a positive effect on biological activity, fertility and productivity (Baldock et al., 2010). The sequestration of carbon in soil has the potential to offset greenhouse gas emissions (i.e., $\mathrm{CO}_{2}, \mathrm{CH}_{4}$, and $\mathrm{N}_{2} \mathrm{O}$ ) associated with climate change (Xun et al., 2010). Practical methods to increase carbon sequestration of particular research were developed. This requires an understanding of the influence of different land-management practices (e.g., tillage) on soil organic carbon (SOC) (Gaiser et al., 2008), which is complicated by the fact that SOC is affected by climate, soil type, vegetation type, topography and land drainage, as well as land management practice (Gami et al., 2009).

Zhao et al. (2017) researched the impact of shifts in land use on SOC in an agropastoral ecotone of Inner Mongolia. Li et al. (2016) estimated the impact of land use change on SOC sequestration in China from 1985 to 2005. However, the effect of shifts in land use on carbon budget in China's arid and semi-arid regions, such as the Shiyang River Basin, has received little attention, which limits our understanding of the mechanisms by which land use change affects the carbon cycle. Poeplau and Don (2015) showed that planting cover crops during winter and tilling them into the soil as additional carbon input can significantly enhance soil $\mathrm{C}$ on croplands.

It is important to identify the relationships between SOC and landscape features and to assess the amount and spatial variability of carbon storage in soils. Physiographic 
characteristics such as altitude, slope and aspect have an influence on the efficiency of carbon sequestration in different regions. Wang et al. (2010) showed that landscape characteristics influenced SOC. They measured lowest organic carbon accumulation in elevated areas and identified a significant negative relationship between SOC and elevation $(\mathrm{r}=-0.429 * *)$. The same relationship also found a significant negative correlation between SOC and slope $\left(\mathrm{r}=-0.195^{* *}\right)$.

Heidari et al. (2010) suggested that the highest levels of carbon are found in areas that have moderate rainfall and low elevation. These factors are unaffected by human activities (i.e., tillage), and have suitable climatic conditions (i.e., temperature and precipitation) so that the growth period is not limited. While the ability to estimate carbon sequestration in a wide range of environments is essential, this has been limited by the complexities of soil characteristics and environmental conditions (Padilla et al., 2010).

Topography is one of the most important factors affecting the amount of organic carbon in soils, but this is not a simple relationship. For example, Senthilkumar et al. (2009) found that the influence of topography on organic carbon storage varied between different agricultural systems. This was attributed to the accumulation of plant residues that affect SOC content in the uppermost 0-30 cm depth of the soil. Soil organic carbon also varies with slope, due the influence of leaching, soil erosion, vegetation, and other physical properties such as soil texture (Boulal and Macpherson, 2010).

Geostatistical methods provide a way of studying and predicting the spatial variability of SOC based on relationships with other soil properties and landscape characteristics (Zhang and McGrath, 2004). These relationships can be expressed as regression models (Vasques et al., 2010), developed using parameters that measured in the field, or for which data already exist (Sarmadian et al., 2010). Motallebi et al. (2011) also estimated soil hydraulic properties (e.g., bulk density, calcium carbonate content, and sand-silt-clay fractions) for a semi-arid region using similar models. However, few studies have examined the spatial patterns of SOC and its relationship with the physiographic properties in semi-arid regions (Heidari et al., 2010; Parvizi et al., 2010).

The objectives of this research were to: (i) investigate the influence of physical and chemical characteristics (e.g., total nitrogen, equivalent calcium carbonates, clay content and $\mathrm{pH}$ ) on SOC and (ii) develop regression models between SOC and different landform types in the Damavand Region of Tehran, Iran.

\section{Materials and methods}

\section{Study area}

The Damavand Region is located in northeast of Tehran in Iran (Fig. 1), covers about 6272 ha at $35^{\circ} 35^{\prime} 55^{\prime \prime}-35^{\circ} 40^{\prime} 37^{\prime \prime} \mathrm{N}$ and $51^{\circ} 59^{\prime} 11^{\prime \prime}-52^{\circ} 11^{\prime} 33^{\prime \prime} \mathrm{E}$. The climate is predominantly dry and cold, with a mean annual precipitation of $322 \mathrm{~mm}$ and a mean annual temperature of $11.6{ }^{\circ} \mathrm{C}$ (1999-2010 data) (Climatic Data Center, 2010). Height above sea level varies between 1800 and $2200 \mathrm{~m}$. The main landforms of the region are "alluvial fans, River Alluvial Plains, and plateaus" and soils classified as Entisols and Inceptisols using the USDA soil classification system (Keys to Soil Taxonomy, 2010).

A digital elevation model (DEM) of the region was developed in Arc-GIS from a topographic map (1:25,000 scale). Physiographic characteristics (slope, altitude, and aspect) were classified using the DEM, and landform units were subsequently 
determined. Landform units were determined by overlaying the slope, hypsometric and aspect maps.

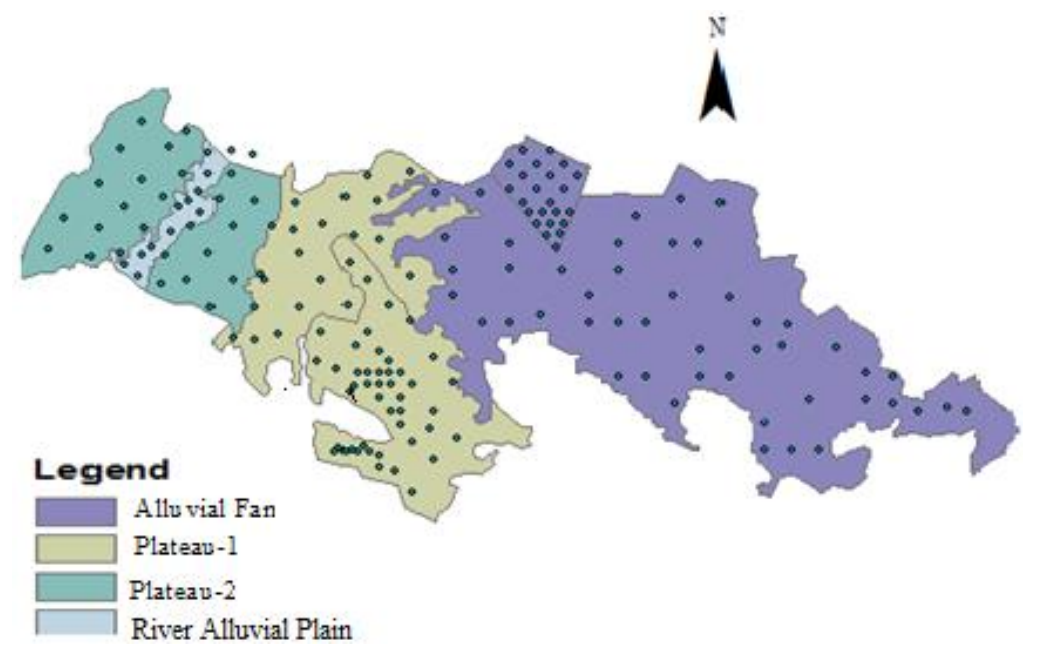

Figure 1. Landform types and sampling sites in the Damavand Region of Tehran, Iran

Dividing the slope according to the irrigation management division and determining the height adjustment according to the type of cover and management changes. Nine elevation classes (1820-1900 m, 1900-1950 m, 1950-1985 m, 1985-2020 m, 2020-2045 $\mathrm{m}, 2045-2075 \mathrm{~m}, 2075-2110 \mathrm{~m}, 2110-2150 \mathrm{~m}, 2150-2200 \mathrm{~m})$, four slope classes $(0-5 \%$, $5-12 \%, 12-25 \%,>25 \%$ ), and four aspects (north, south, west, east) were defined. $\mathrm{ETM}+$ satellite images (from 2002), Indian Remote Sensing (IRS) satellite images (from 2007), and Moderate Resolution Imaging Spectroradiometer (MODIS) satellite images (from 2010) of the region were analyzed to delineate land type boundary from Rs and using GIS software. The use of remotely sensed data from satellite imagery or aerial photography has become commonplace in soil management studies (Karl and Maurer, 2010).

\section{Soil sampling}

Soil samples were collected from 0-25 cm soil depth, for each land unit. Sampling was done with a shovel of about $2 \mathrm{~kg}$. Average slopes of alluvial fan 0-5\% and clay loam texture, Plateau 1: average slopes $5-8 \%$ and silty clay loam texture, Plateau 2: average slopes $8-12 \%$ and sandy loam texture, River Alluvial Plains: average slopes 0$5 \%$ and loam texture. They were classified based on the relative area under each soil type, land use, slope, aspect, and elevation class. The plateau was divided into two groups due to the type of cover and management. The total number of 1607 sites was initially classified. According to the Minimum Decision Area (MDA) (Eq. 1), areas less than 10 ha were merged with neighbor polygons, reducing the number of sites by 160 , as follows:

$$
\operatorname{MDA}(\mathrm{hac})=1.6 \mathrm{~cm}^{2} \times 10^{-8}\left(\text { hac. } \mathrm{cm}^{2}\right)\left(\text { Scalefactor. } . \mathrm{mm}^{-1}\right)
$$

Sampling sites were located in the field using GPS in October 2010. At each sampling location, three separate points (approximately $10 \mathrm{~m}$ apart) was sampled at 0 
$30 \mathrm{~cm}$ soil depth. These three individual samples were combined to form a single bulk sample for each site. Samples were sealed in plastic bags and transported to the laboratory. At each location, recorded the latitude longitude, landscape position, slope class, aspect, elevation, land cover, and land management practice.

\section{Laboratory analysis}

Soil samples were air-dried and sieved in the laboratory to retain the $<2 \mathrm{~mm}$ fraction. Soil pH was measured in a 1:1 suspension of soil and distilled water (McLean, 1982). Soil texture was measured using hydrometer method (Bouyoucos, 1962). Soil organic carbon was determined using the Walkey-Black method (Walkley and Black, 1934). Bulk density (BD) was measured using standard paraffin wax procedures. (USDA, 1995). Total Nitrogen (TN) was determined using the Kjeldahl method (USDA, 1995). Calcium carbonate equivalent (T.N.V), was measured using the Acidimetric method, which involved neutralization of the sample by a titrated acid. Back-titration using a base that used to determine $\mathrm{CaCO} 3$ content (USDA, 1995). Particle size distribution was determined using the hydrometer method (Gee and Bauder, 1979).

\section{Statistical analysis}

Descriptive statistical parameters for SOC were determined, including the mean, median, skewness, kurtosis, standard deviation, variance, coefficients of variation, maximum and minimum. Pearson correlation coefficients (r) were estimated for all possible paired combinations of the response variables to generate a correlation coefficient matrix. Kolmogorov-Smirnov tests showed that the data were not normally distributed; consequently, non-parametric tests were used. The Kruskal-Wallis test was used to assess differences in SOC between land units (Mills and Cowling, 2010). Simple linear regression, multiple regression, and simple nonlinear regression methods of predicting SOC were assessed. The limiting stepwise regression was applied on the input variables to prevent internal regression.

The performance of the regression models were evaluated by cross validation, where estimated and observed values are compared at each of the observed value location. Reliability of the models evaluated with an independent dataset. Estimated and observed values were compared using two criteria: mean absolute error (MAE) and mean bias error (MBE) (Eqs. 2 and 3):

$$
\begin{gathered}
M A E=\frac{1}{n} \sum_{i=1}^{n}\left|z^{*}\left(x_{i}\right)-z\left(x_{i}\right)\right| \\
\mathrm{MBE}=\frac{1}{\mathrm{n}} \sum_{\mathrm{i}=1}^{\mathrm{n}}\left(\mathrm{z}^{*}\left(\mathrm{x}_{\mathrm{i}}\right)-\mathrm{z}\left(\mathrm{x}_{\mathrm{i}}\right)\right)
\end{gathered}
$$

where $\mathrm{z}^{*}(\mathrm{xi})$ is the value to be estimated at the location of $\mathrm{xi}, \mathrm{z}$ (xi) the known value at the sampling site $\mathrm{xi}$ and $\mathrm{n}$ is the number of sites.

Geostatistical analysis was also used to infer the spatial variation of SOC at each site. The spatial distribution of SOC was predicted by the IDW method. In this study, the geostatistical analyses were produced with GIS software ArcGIS (version 9.3). 


\section{Results}

The results showed that there are significant differences of the Kruskal-Wallis $(\mathrm{p}<0.01)$ test between soil organic carbon contents of the four land types (Table 1).

Table 1. Comparing SOC among land forms ranks

\begin{tabular}{c|c|c}
\hline Landform-code & N & Mean rank \\
\hline Alluvial fan (irrigated farming lands) & 54 & 89.62 \\
Plateau1 (dry farming) & 56 & 66.29 \\
Plateau2 (rangeland) & 30 & 44.12 \\
River alluvial plain (garden) & 12 & 146.08 \\
\hline Total & 152 & \\
\hline
\end{tabular}

The highest SOC was measured in River Alluvial Plain soils (mean SOC $=22.04 \mathrm{~g} \mathrm{~kg}^{-1}$ ), followed by alluvial fan soils (mean $\mathrm{SOC}=7.75 \mathrm{~g} \mathrm{~kg}^{-1}$ ), plateau 1 soils (mean $\mathrm{SOC}=6.17 \mathrm{~g} \mathrm{~kg}^{-1}$ ), and plateau 2 soils $\left(\mathrm{SOC}=4.92 \mathrm{~g} \mathrm{~kg}^{-1}\right)$. The mean SOC value for the study area was $7.73 \mathrm{~g} \mathrm{~kg}^{-1}$ (Table 2).

Table 2. Descriptive analysis of soil variables

\begin{tabular}{c|c|c|c|c|c}
\hline \multirow{2}{*}{ Parameter } & \multicolumn{5}{|c}{ Land type } \\
\cline { 2 - 6 } & Total area & Alluvial fan & Plateau 1 & Plateau 2 & River alluvial plain \\
\hline Mean & 7.74 & 7.750 & 6.170 & 4.920 & 22.05 \\
Median & 6.93 & 6.840 & 5.830 & 4.620 & 22.10 \\
Variance & 2.55 & 6.539 & 2.710 & 5.800 & 20.60 \\
Std. deviation & 5.05 & 2.980 & 1.650 & 2.410 & 4.54 \\
Skewness & 2.42 & 2.282 & 0.422 & 0.447 & 1.22 \\
Kurtosis & 6.57 & 6.539 & -0.022 & -0.684 & 2.56 \\
Min & 0.91 & 3.695 & 2.920 & 0.914 & 16.25 \\
Max & 33.16 & 20.222 & 10.210 & 9.250 & 33.16 \\
\hline
\end{tabular}

To explain the spatial variability of SOC, the Inverse Distance Weighting (IDW) method was used. The organic carbon content was low for soils sampled from several sites in the study area, which was the main factor in their low fertility status. The distribution of organic carbon in the upper profile $(0-30 \mathrm{~cm})$ of soils is shown in Figure 2.

The results showed that soil organic carbon ranged from $0.1 \%$ to $3.2 \%\left(1-32 \mathrm{~g} \mathrm{~kg}^{-1}\right)$ in the study area. Organic carbon was very low in the some part of plateau with SOC $<4 \mathrm{~g} \mathrm{~kg}^{-1}$ and higher SOC $>16 \mathrm{~g} \mathrm{~kg}^{-1}$ in the all part of River Alluvial Plain.

The area under each land form had normal distribution (Kolmogorov-Smirnov test). Except total area and alluvial fan, the data distributed abnormal. Based on the result of this table, soil organic carbon was significantly positively correlated with $\% \mathrm{~N}$ $\left(\mathrm{r}=0.962^{* *}, \mathrm{P}<0.01\right)$ in total area. In general, the value of $\mathrm{N}$ significantly affected SOC for all landform classifications (Table 3). 


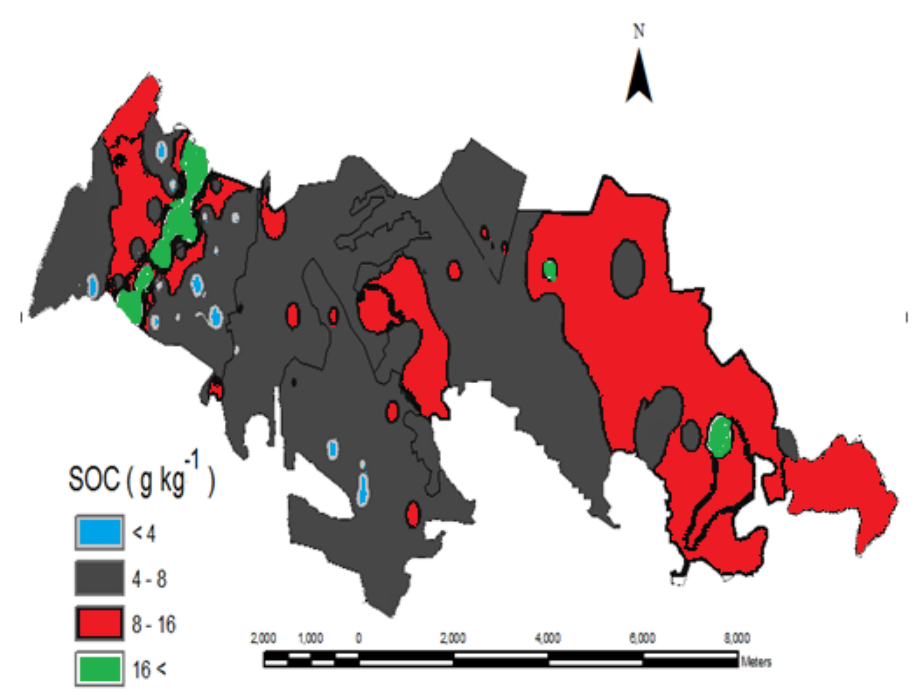

Figure 2. Distribution of organic carbon in the study area

Table 3. Pearson correlations among soil physical, chemical variables and organic carbon in land form classification

\begin{tabular}{c|c|c|c|c|c}
\hline Land type & Total area & Alluvial fan & Plateau 1 & Plateau 2 & River alluvial plain \\
\hline Variable & $\% \mathrm{~N} \% \mathrm{~T} . \mathrm{N} . \mathrm{V} \mathrm{pH}$ & $\% \mathrm{~N}$ & $\% \mathrm{~N}$ & $\% \mathrm{~N}$ Clay & $\% \mathrm{~N}$ \\
$\mathrm{r}$ & $0.962 * * 0.407^{*}-0.447 *$ & $0.893^{* *}$ & $0.609 *$ & $0.730^{* *} 0.838^{* *}$ & $0.960 * *$ \\
$\mathrm{n}$ & 152 & 54 & 56 & 30 & 12 \\
\hline
\end{tabular}

**Correlation is significant at the 0.01 level (2-tailed)

*Correlation is significant at the 0.05 level (2-tailed)

Linear and nonlinear regression equations to predict SOC from physiographic variables are shown in Table 3. For all landform types, TN had the highest correlation with SOC. There were significant differences between the types of landform $\left(\mathrm{r}=0.99^{* *}, \mathrm{p}<0.01\right)$. For each landform, two linear regression model and one nonlinear regression model were developed to predict SOC. In all equations, all or one of the independent variables such as TN, Clay, $\mathrm{pH}, \mathrm{Bd}$ was used (Table 4).

Comparing nonlinear models in all land types, indicate that cubic models has highest coefficient of multiple determination (Table 4), and it is fitted for predicting SOC. Estimating regression models in each land type indicated, the models had not any over estimation or under estimation because MBE index was nearly zero (Table 5).

MAE value was greater in River Alluvial Plain than any other land types; which means high error in that location. Measured and predicted values were compared using the t-student test. Results showed no significant difference between them in each land type. This means that predicted models is approved and the relationship is reliable.

The significance level of coefficients in each land type for regression models was determined: for River Alluvial Plain, alluvial fan and total area; Correlation coefficient is significant at the 0.01 level. For Plateau 1 and Plateau 2; Correlation is significant at the 0.05 level. Standard Error was calculated 1.01, 0.33, 0.5 and 0.61 for River Alluvial Plain, alluvial fan, Plateau 1 and Plateau 2, respectively. 
Table 4. Regression models used to estimate SOC

\begin{tabular}{|c|c|c|c|}
\hline Land types & Regression & Regression equation & $\mathbf{r}$ \\
\hline \multirow{3}{*}{ Alluvial fan } & & $\mathrm{OC}\left(\mathrm{g} \mathrm{kg}^{-1}\right)=-2.475+10.882 \mathrm{~N}\left(\mathrm{~g} \mathrm{~kg}^{-1}\right)$ & 0.797 \\
\hline & Linear & $\begin{array}{c}\mathrm{OC}\left(\mathrm{g} \mathrm{kg}^{-1}\right)=17.725+7.488 \mathrm{~N}+0.004 \text { T.N.V-3.082 pH-0.003 } \\
\text { gravel + 2.615 Bd + 0.001 Clay + 0.003 Sand }\end{array}$ & 0.830 \\
\hline & Nonlinear & $\mathrm{OC}\left(\mathrm{g} \mathrm{kg}^{-1}\right)=15.172-26.57 \mathrm{~N}+19.458 \mathrm{~N}^{2}$ & 0.837 \\
\hline \multirow{3}{*}{ Plateau 1} & & $\mathrm{OC}\left(\mathrm{g} \mathrm{kg}^{-1}\right)=4.42+3.21 \mathrm{~N}$ & 0.371 \\
\hline & Linear & $\begin{aligned} \mathrm{OC}\left(\mathrm{g} \mathrm{kg}^{-1}\right) & =51.941+1.99 \mathrm{~N}+0.003 \text { T.N.V-5.656 } \mathrm{pH}+0.003 \\
& \text { gravel-0.17 Bd-0.006 Silt-0.009 Sand }\end{aligned}$ & 0.537 \\
\hline & Nonlinear & $\mathrm{OC}\left(\mathrm{g} \mathrm{kg}^{-1}\right)=-4.258+27.216 \mathrm{~N}-14.27 \mathrm{~N}^{2}$ & 0.681 \\
\hline \multirow[t]{2}{*}{ Plateau 2} & Linear & $\begin{array}{c}\mathrm{OC}\left(\mathrm{g} \mathrm{kg}^{-1}\right)=1.041+9.34 \mathrm{~N} \\
\mathrm{OC}\left(\mathrm{g} \mathrm{kg}^{-1}\right)=-0.467+0.012 \text { Clay }+6.085 \mathrm{~N}\end{array}$ & $\begin{array}{l}0.533 \\
0.742\end{array}$ \\
\hline & Nonlinear & $\mathrm{OC}\left(\mathrm{g} \mathrm{kg}^{-1}\right)=\mathrm{e}^{2.475-0.365 / \mathrm{N}}$ & 0.681 \\
\hline \multirow{2}{*}{$\begin{array}{l}\text { River } \\
\text { alluvial } \\
\text { plain }\end{array}$} & Linear & $\begin{array}{c}\mathrm{OC}\left(\mathrm{g} \mathrm{kg}^{-1}\right)=-1.699+11.725 \mathrm{~N} \\
\mathrm{OC}\left(\mathrm{g} \mathrm{kg}^{-1}\right)=-2.837+11.539 \mathrm{~N}+0.005 \text { Clay }\end{array}$ & $\begin{array}{l}0.921 \\
0.922\end{array}$ \\
\hline & Nonlinear & $\mathrm{OC}\left(\mathrm{g} \mathrm{kg}^{-1}\right)=26.582-15.696 \mathrm{~N}+6.431 \mathrm{~N}^{2}$ & 0.948 \\
\hline \multirow{2}{*}{ Total area } & Linear & $\begin{array}{c}\mathrm{OC}\left(\mathrm{g} \mathrm{kg}^{-1}\right)=-0.216+10.061 \mathrm{~N} \\
\mathrm{OC}\left(\mathrm{g} \mathrm{kg}^{-1}\right)=15.5+10.161 \mathrm{~N}+0.004 \text { T.N.V-2.21 } \mathrm{pH}\end{array}$ & $\begin{array}{l}0.925 \\
0.930\end{array}$ \\
\hline & Nonlinear & $\mathrm{OC}\left(\mathrm{g} \mathrm{kg}^{-1}\right)=2.912+2.924 \mathrm{~N}+2.935 \mathrm{~N}^{2}$ & 0.947 \\
\hline
\end{tabular}

Table 5. Index assessment and significant regression models

\begin{tabular}{c|c|c|c|c}
\hline Land types & Model & The correlation coefficient & MBE & MAE \\
\hline Alluvial fan & Nonlinear & 0.84 & 0.0 & 0.73 \\
Plateau 1 & Nonlinear & 0.68 & 0.0 & 0.81 \\
Plateau 2 & Multiple linear & 0.74 & 0.0 & 0.8 \\
River alluvial plain & Nonlinear & 0.95 & 0.0 & 0.9 \\
\hline
\end{tabular}

\section{Discussion}

The Pearson's linear correlation analysis revealed a significant positive relationship between SOC and total nitrogen. The highest organic carbon contents measured in soils from the highest storage of $\mathrm{N}$ accumulation. It can be assumed that that $\mathrm{TN}$ affected SOC status significantly. It assumed that $\mathrm{TN}$ has a positive benefit in maintaining and restoring the SOC quality and quantity for cropland in the study area. In similar research, Parvizi (2010) showed that physical variables and land use type can identify carbon sources. In that research, regression models were developed in forestry with a higher coefficient.

In some land types, there was significant correlation between clay and SOC; it is assumed clay protects organic matter from decomposition and runoff. For instance, Kasel et al. (2011) investigated that across north-central Victoria in south-eastern of Australia, mean rates of SOC accumulation in whole soils were greater increase under 
the N-fixing trees. There was poor correlation between SOC and clay content across sites due to the clay mineralogy.

Differences in accumulation of SOC may also be related to physiographic condition such as slope, aspect, elevation, land use, the structure of root systems that could contribute to SOC distribution.

Soil organic carbon originates primarily from plants, thus vegetation and land use history is one of the most important driving factors of SOC (Jafarian and Kavian, 2013; González et al., 2010; Strickland et al., 2010). Accurate and reliable estimates of SOC storage in landscapes and land use are critical to the development of effective policies and strategies to mitigate atmospheric and climate change (Sylvia et al., 2016; Lufafa et al., 2008; Zhao et al., 2010). This research was provided where these findings were used to create a reference of regression models. This information was found to be valuable in supporting the evaluation of SOC field surveys, which are increasingly becoming available. I would also recommend to search on available topographic and management variables to develop models to estimate soil organic carbon.

\section{Conclusion}

Soil organic carbon in the land forms of the study area was abnormal, and had an arithmetic mean of $7.7 \mathrm{~g} \mathrm{~kg}^{-1}$. The highest organic carbon content $\left(22.04 \mathrm{~g} \mathrm{~kg}^{-1}\right)$ was in River Alluvial Plain region that has lowest elevation, and include river surrounded by river sediment. This fertility area was used for garden utilization. These results explained relationships between organic carbon and land types and land use attributes. In some parts of alluvial fan, including cropland utilization, the level of soil organic carbon (7.75 $\mathrm{g} \mathrm{kg}^{-1}$ ) could be explained by the input of litter, organic manure, decomposition and loss by the soil erosion. Addition of chemical fertilizer and manure could increase SOC in topsoil. Chemical fertilizer can increase root production of crops and products' yield, subsequently increasing organic residue input into the soil.

Acknowledgements. The author would like to thank Islamic Azad University of Roudehen for financial support.

\section{REFERENCES}

[1] Baldock, J. A., Sanderman, J., Farquharson, R. (2010): Capturing carbon in Australian soils: Potential and realities. - 19th World Congress of Soil Science, Soil Solutions for a Changing World.

[2] Boulal, H., Gómez-Macpherson, H. (2010): Dynamics of soil organic carbon in an innovative irrigated permanent bed system on sloping land in southern Spain. Agriculture, Ecosystems \& Environment 139: 284-292.

[3] Bouyoucos, G. J. (1962): Hydrometer method improved for making particle size analysis of soils. - Agronomy. J 54: 464-465.

[4] Climatic Data Center (2010): Meteorological Stations of Homand Absard 1999-2010. http://reports.irimo.ir/jasperserver/login.html.

[5] Gaiser, T., Stahr, K., Billen, N., Razek Mohammad, M. A. (2008): Modeling carbon sequestration under zero tillage at the regional scale. I. The effect of soil erosion. Ecological Modelling 218: 110-1 20. 
[6] Gami, S. K., Lauren, J. G., Duxbury, J. M. (2009): Influence of soil texture and cultivation on carbon and nitrogen levels in soils of the eastern Indo-Gangetic plains. Geoderma 153: 304-311.

[7] Gee, G. W., Bauder, J. W. (1979): Particle size analysis by hydrometer- a simplified method for routine textural analysis and a sensitivity test of measurement parameters. Soil Science Society of America Journal 43: 1004-1007.

[8] González, L., Etchevers, J. D., González, J. M., Paz, F. (2010): Soil organic carbon changes at the plot level in hillside systems. - Agriculture, Ecosystems \& Environment DOI: $10.1016 /$ j.agee,2010.09.010.

[9] Heidari, A., Faghih, A., Gorji, M. (2010): Carbon sequestration under different physiographic and climatic conditions in north Karaj river basin. - 19th World Congress of Soil Science, Soil Solutions for a Changing World, Brisbane, Australia, 1-6 August, pp. 9-11.

[10] Jafarian, Z., Kavian, A. (2013): Effects of land-use change on soil organic carbon and nitrogen. - Communications in Soil Science and Plant Analysis 44(1-4): 339-346.

[11] Karl, J. W., Maurer, B. A. (2010): Spatial dependence of predictions from image segmentation: A variogram-based method to determine appropriate scales for producing land-management information. - Ecological Informatics 5: 194-202.

[12] Kasel, S., Singh, S., Sanders, G. J., Bennett, L. T. (2011): Species-specific effects of native trees on soil organic carbon in biodiverse plantings across north-central Victoria, Australia. - Geoderma 161: 95-106.

[13] Lufafa, A., Diédhiou, I., Samba, S., Séné, M., Khouma, M., Kizito, F., Dick, R. P., Dossa, E., Noller, J. S. (2008): Carbon stocks and patterns in native shrub communities of Senegal's Peanut Basin. - Geoderma 146: 75-82.

[14] Li, M., Wu, J., Deng, X. (2016): Land use change and soil carbon sequestration in China: Where does it pay to conserve? - Reg. Environ. Chang. 16: 2429-2441.

[15] McLean, E. O. (1982): Soil pH and Lime Requirement. - In: Page, A. L, Miller, R. H., Keeney, D. R. (eds.) Methods of Soil Analysis. Part 2. Chemical and Microbiological Properties. 2nd ed. Agronomy Monograph 9: pp. 199-224. ASA and SSSA, Madison, WI.

[16] Mills, A. J., Cowling, R. M. (2010): Below-ground carbon stocks in intact and transformed subtropical thicket landscapes in semi-arid South Africa. - Journal of Arid Environments 74: 93-100.

[17] Motallebi, E., Homaee, M., Zarei, G., Mahmoudi, S. (2011): The effect of lime on soil moisture characteristics with using pedo transfer function in Garmsar series. - Iranian Journal of Irrigation and Drainage 3(4): 426-439.

[18] Padilla, F. M., Vidal, B., Sanchez, J., Pugnaire, F. I. (2010): Land-use changes and carbon sequestration through the twentieth century in a Mediterranean mountain ecosystem: Implications for land management. - Journal of Environmental Management 91: 2688-2695.

[19] Parvizi, Y. (2010): Zoning spatial variability of soil organic carbon and the effect of physical and managerial factors that analysts use multivariate and artificial neural networks. $-\mathrm{PhD}$. Thesis, Agricultural Engineering and Technology Department, Tehran University, Iran.

[20] Poeplau, C., Don, A. (2015): Carbon sequestration in agricultural soils via cultivation of cover crops - A meta-analysis. - Agr. Ecosyst. Environ. 200: 33-41.

[21] Sarmadian, F., Taghizadeh Mehrjardi, R. (2010): Development of pedotransfer functions to predict soil carbon properties in Golestan Province, Iran. - 19th World Congress of Soil Science, Soil Solutions for a Changing World. Brisbane, Australia.

[22] Senthilkumar, S., Kravchenko, A. N., Robertson, G. P. (2009): Topography Influences management system effects on total soil carbon and nitrogen. - Soil Science Society of America Journal 73: 2059-2067. 
[23] Sylvia, S., Julia, E. M. S, Pongratz, J. (2016): Soil carbon response to land-use change: evaluation of a global vegetation model using observational meta-analyses. Biogeosciences 13: 5661-5675.

[24] Strickland, M. S., Callaham, Jr. M. H., Davies, C. A., Lauber, C. L., Ramirez, K., Richter, Jr. D. D., Fierer, N., Bradford, M. A. (2010): Rates of in situ carbon mineralization in relation to land-use, microbial community and edaphic characteristics. - Soil Biol Biochem 42: 260-269.

[25] U. S. Department of Agriculture, Natural Resources Conservation Service (USDANRCS) (1995): Soil Survey Laboratory Information Manual. - Soil Survey Investigations Report No. 45.

[26] Vasques, G. M., Grunwald, S., Comerford, N. B., Sickman, J. O. (2010): Regional modeling of soil carbon at multiple depths within a subtropical watershed. - Geoderma 156: 326-336.

[27] Walkley, A., Black, I. A. (1934): An examination of the Degtjareff method for determining soil organic matter and a proposed modification of the chromic acid titration method. - Soil Science 37: 29-38.

[28] Wang, Z. M., Zhang, B., Song, K. S., Liu, D. W., Ren, C. Y. (2010): Spatial variability of soil organic carbon under maize monoculture in the Song-Nen Plain, Northeast China. Pedosphere 20(1): 80-89.

[29] Xun, L., Feng-Min, L., Da-Qian, L., Guo-Jun, S. (2010): Soil organic carbon, carbon fractions and nutrients as affected by land use in semi-arid region of Loess Plateau of China. - Pedosphere 20(2): 146-1 52.

[30] Zhang, C. S., McGrath, D. (2004): Geostatistical and GIS analyses on soil organic carbon concentrations in grassland of southeastern Ireland from two different periods. Geoderma 119: 261-275.

[31] Zhao, S. Q., Liu, S., Li, Z., Sohl, T. L. (2010): Spatial resolution thresholds of land cover in estimating terrestrial carbon sequestration in four counties in Georgia and Alabama, USA. - Biogeosciences 7: 71-80.

[32] Zhao, W., Hu, Z. M., Li, S. G., Guo, Q., Yang, H., Zhang, T. H. (2017): Impact of land use conversion on soil organic carbon stocks in an agro-pastoral ecotone of Inner Mongolia. - J. Geogr. Sci. 27: 999-1010. 